\title{
PEMANTAPAN MATERI MATEMATIKA KUBUS DI SEKOLAH MENENGAH PERTAMA (SMP) ISLAM AL- ISTIQOMAH DAN MTS AL-HIDAYAH
}

\author{
The Construction Materials of Cube Mathematic At Junior High Islamic Schools Al- \\ Istiqomah And Mts Al-Hidayah \\ Nur Arifiya*, Rini Setiowati, Ratih Ikha Permata Sari \\ Fakultas Teknik Industri dan Ilmu Komputer, Universitas Indraprasta PGRI Jakarta \\ *email: pipiya27@gmail.com
}

\begin{abstract}
ABSTRAK
Pada jenjang Sekolah Menengah Pertama para siswa diperkenalkan dengan bangun ruang kubus yang merupakan salah satu bentuk dari materi geometri. Secara bahasa, kubus adalah suatu bangun ruang yang dibatasi oleh enam buah persegi yang sepasang-sepasang sejajar dan setiap tiga persegi yang berdekatan saling tegak lurus. Dengan penguasaan konsep materi dari kubus yang baik, maka siswa dapat terlatih untuk jeli dalam menganalisa suatu objek dan informasi dan tidak mudah terkecoh. Kurangnya kesadaran siswa terkait pentingnya pemahaman materi kubus dalam matematika maka dianggap perlu adanya program pemantapan, guna meningkatkan pemahaman siswa. Modul merupakan bahan ajar yang disusun secara sistematis dengan bahasa yang mudah dipahami oleh siswa, Kegiatan belajar mengajar yang dilakukan sangat bermanfaat sekali bagi siswa-siswi dan terlihat mereka sangat antusias dalam mengikuti kegiatan, mulai dari perkenalan, pertanyaan di awal pertemuan, penyampaian materi sampai akhir pembelajaran, hingga pertanyaan di akhir.
\end{abstract}

Kata Kunci : Konsep Pemahaman Kubus

\section{ABSTRACT}

At the level of junior high school students are introduced to building a cube space which is one form of geometry material. In language, the cube is a building that is bounded by six square pieces in parallel pairs and each of the three adjacent squares perpendicular to each other. By mastering the material concepts of a good cube, students can be trained to be observant in analyzing an object and information and not easily fooled. Lack of student awareness regarding the importance of understanding cube material in mathematics is considered necessary for a stabilization program, in order to improve student understanding. Modules are teaching materials that are arranged systematically in a language that is easily understood by students. The teaching and learning activities carried out are very beneficial for students and they are very enthusiastic in participating in the activities, starting from introductions, questions at the beginning of the meeting, delivery of material to end of learning, until the question at the end.

Keywords: Concept of Understanding Cubes 


\section{Pendahuluan}

Pada jenjang Sekolah Menengah Pertama para siswa diperkenalkan dengan bangun ruang kubus yang merupakan salah satu bentuk dari materi geometri. Menurut Clemens (1985), geometri merupakan bagian matematika yang membahas tentang bentuk dan ukuran dari suatu obyek yang memiliki keteraturan tertentu. Secara bahasa, kubus adalah suatu bangun ruang yang dibatasi oleh enam buah persegi yang sepasang-sepasang sejajar dan setiap tiga persegi yang berdekatan saling tegak lurus. Dengan penguasaan konsep materi dari kubus yang baik, maka siswa dapat terlatih untuk jeli dalam menganalisa suatu objek dan informasi dan tidak mudah terkecoh.

Kurangnya kesadaran siswa terkait pentingnya pemahaman materi kubus dalam matematika maka dianggap perlu adanya program pemantapan, guna meningkatkan pemahaman siswa. Oleh karena itu, dalam rangka memberikan dan meningkatkan pelayanan kepada para siswa pada mutu pendidikan, maka dipandang perlu untuk membuat program pemantapan atau istilah lainnya adalah belajar tambahan yang bertujuan untuk memberikan bimbingan agar siswa memiliki konsep pemahaman materi yang kuat. Dengan adanya program bimbingan belajar dalam bentuk pemantapan penguasaan materi ini, diharapkan akan membantu para siswa untuk meningkatkan nilai akademisnya.

Selain itu, keberhasilan dari proses belajar mengajar juga ditunjang oleh media yang digunakan pada saat membahas bahan ajar khususnya materi 3 dimensi kubus. Oleh karena itu, diperlukan media yang mampu menunjang para siswa dalam memahami materi pelajaran guna mengoptimalkan hasil belajar dan capaian nilai akademis. Salah satu media yang dapat diberikan adalah memfasilitasi siswa dengan modul.

Oleh karena itu, dalam pengajaran kali ini menggunakan alat peraga yang terbuat dari bahan karton agar ilustrasi bangun ruang kubus dapat tervisualisasi oleh siswa secara optimal.

\section{Metode}

\section{Modul dan Alat Peraga}

Menurut Andi Prastowo (2012) modul merupakan bahan ajar yang disusun secara sistematis dengan bahasa yang mudah dipahami oleh siswa, sesuai usia dan tingkat pengetahuan mereka agar mereka dapat belajar secara mandiri dengan bimbingan minimal dari pendidik. Pandangan serupa 
juga dikemukakan oleh Sukiman (2011) yang menyatakan bahwa modul adalah bagian kesatuan belajar yang terencana yang dirancang untuk membantu siswa secara individual dalam mencapai tujuan belajarnya. Siswa yang memiliki kecepatan tinggi dalam belajar akan lebih cepat menguasai materi. Sementara itu, siswa yang memiliki kecepatan rendah dalam belajar bisa belajar lagi dengan mengulangi bagian-bagian yang belum dipahami sampai paham.

Depdiknas (2003) dalam kurikulum 2006 mengasumsikan adanya integrasi antara penguasaan kompetensi dan pengembangan life skill/ kecakapan hidup. Tim Broad-Based education, Depdiknas (2002) mengartikan life skill sebagai kecakapan yang dimiliki seseorang untuk berani menghadapi problema kehidupan dengan wajar tanpa merasa tertekan, kemudian secara proaktif dan kreatif mencari dan menemukan solusi sehingga akhirnya mampu mengatasinya. Kecakapan tersebut meliputi: (1) kecakapan pribadi (personal skill), yakni kecakapan mengolah diri pribadi yang mencakup aspek-aspek jasmani, perasaan, pikiran, dan spiritual; (2) kecakapan sosial (social skill), yakni kecakapan membangun hubungan positif dengan orang lain; (3) kecakapan akademik (academic skill), yakni kecakapan menguasai pelajaran di sekolah; (4) kecakapan vokasional (vocational skill), yakni kecakapan melakukan praktek kerja dalam kehidupan sehari-hari yang terkait dengan pelajaran di sekolah.

Alat peraga merupakan bagian dari media pengajaran, oleh karena itu istilah media perlu dipahami lebih dahulu sebelum dibahas mengenai pengertian alat peraga lebih lanjut. Media pengajaran diartikan sebagai semua benda yang menjadi perantara terjadinya proses belajar, dapat berwujud sebagai perangkat lunak maupun perangkat keras. Menurut Elly Estiningsih dalam Pujiati (2004) berdasarkan fungsinya media pengajaran dapat berbentuk alat peraga dan sarana. Menurut Nasution (2000), alat peraga adalah alat pembantu dalam mengajar agar efektif. Pendapat lain dari Suhardi (1998) menyatakan pengertian alat peraga atau Audio Visual Aids (AVA) adalah media yang pengajarannya berhubungan dengan indera pendengaran. Sejalan dengan itu Sumadi (2002) mengemukakan bahwa alat peraga adalah alat untuk memberikan pelajaran atau yang dapat diamati melalui panca indera. Alat peraga merupakan salah satu dari media pendidikan adalah alat untuk membantu proses belajar mengajar agar proses 
komunikasi dapat berhasil dengan baik dan efektif. Hal ini sesuai dengan pendapat Amir Hamzah (2001) bahwa media pendidikan adalah alat-alat yang dapat dilihat dan didengar untuk membuat cara berkomunikasi menjadi efektif.

\section{Target}

Peserta kegiatan ini adalah siswasiswi kelas 8 (Delapan) di SMPI Istiqomah dan MTs Al-Hidayah. Meskipun dengan sarana dan prasarana yang terbatas, diharapkan kepala sekolah, para guru, dan siswa-siswi saling bekerja sama guna tercapainya keberhasilan dari kegiatan pembelajaran.

Materi pokok yang diberikan guru kepada siswa-siswi hendaknya dua arah, yaitu: siswa-siswi terlibat langsung dan aktif di dalam kelas sehingga pembelajaran menjadi bermakna. Dengan pengenalan dan penggunaan modul dan alat peraga sebagai media penunjang diharapkan dapat memudahkan siswa dan guru dalam menguasai materi, sehingga output yang dihasilkan akan optimal.

Maksud dan tujuan yang ingin diperoleh dari kegiatan ini diantaranya adalah

1. Memperkenalkan anak manfaat mempelajari Matematika, khususnya ilmu tentang bangun ruang kubus.
2. Mengarahkan siswa untuk terampil dan terlatih memecahkan persoalan seputar kubus yang ditunjang dengan pemberian modul dan alat peraga pada saat pemantapan, sehingga mampu meningkatkan nilai akademis dari sebagian besar siswa sebagai indikasi keberhasilan belajar.

\section{Metode Pelaksanaan}

\section{Waktu pelaksanaan}

Kegiatan pengabdian masyarakat ini dimulai dengan mengurus perizinan dan peninjauan daerah mitra yang dilakukan bulan September 2018, proses persiapan sosialisasi pentingnya memiliki konsep yang kuat terhadap pelajaran Matematika khususnya bab bangun ruang kubus agar mampu meningkat intelegensi siswa-siswi di tingkat Sekolah Menengah Pertama. Pelaksanaan kegiatan pengabdian masyarakat dilakukan pada bulan September 2018.

\section{Metode Kegiatan}

1. Observasi langsung

Observasi langsung yakni pengabdian langsung datang ke lokasi pengabdian untuk memperolah data. Hal ini kami lakukan pada saat menjelang maupun saat kegiatan berlangsung. Observasi berguna untuk mengetahui kondisi anak-anak di SMPI Al- 
Istiqomah dan MTs Al-Hidayah dalam penerapan pengadaan proses pemantapan belajar yang difasilitasi dengan modul dan alat peraga sebagai upaya mengoptimalkan pemahaman para siswa terhadap materi dari suatu mata pelajaran sebelum melaksanakan ujian sekolah.

2. Penyuluhan

Yaitu tim pelaksana pengabdian masyarakat mengadakan tatap muka dengan siswa-siswi SMPI Al-Istiqomah dan MTs Al-Hidayah guna menjelaskan konsep materi kubus dan memberikan contohcontoh soal yang disertai pembahasan dari bab tersebut.

\section{Hasil dan Pembahasan}

Sesuai dengan rencana yang telah disepakati sebelumnya dengan pihak sekolah, presentasi dilaksanakan pada hari senin, 15 Oktober 2018. Presentasi dilakukan di kelas VIII (delapan) SMPI AlIstiqomah pada pukul 13.00 dan MTs AlHidayah pada pukul 10.00. Waktu yang diberikan oleh pihak sekolah ternyata memang bertepatan dengan jam pelajaran Matematika, sehingga presentasi ini sesuai dengan materi yang sedang dipelajari oleh siswa kelas VIII.

Tahapan selanjutnya adalah pemaparan materi yang dibantu dengan modul dan presentasi dari kami. Pada tahap ini, materi yang dijelaskan adalah tentang konsep kubus sampai dengan perhitungan di SMPI Al-Istiqomah dan MTs AlHidayah kelas VIII, materi disampaikan dengan bantuan modul dan jarring-jaring kubus yang kamis buat. Hal ini agar siswasiswi lebih mudah memahami tentang jaring-jaring kubus dan untuk, materi luas, keliling dan volume menggunakan contoh soal beserta penyelesaian.

Kegiatan belajar mengajar yang dilakukan sangat bermanfaat sekali bagi siswa-siswi dan terlihat mereka sangat antusias antusias dalam mengikuti kegiatan, mulai dari perkenalan, pertanyaan di awal pertemuan, penyampaian materi sampai akhir pembelajaran, hingga pertanyaan di akhir. Siswa-siswi merasa tertantang untuk menjawab setiap kali diberikan pertanyaan.

Di awal kegiatan tim mengajak siswa untuk berdiskusi dan berdialog tentang materi kubus yang diketahui. Mulai dari konsep hingga perhitungan sederhana. Siswa-siswi sangat antusias berusaha menjawab meski masih banyak yang belum mereka kuasai. Dengan demikian tim dapat mengetahui sejauh mana pengetahuan dan pemahaman tentang kubus yang dimiliki siswa-siswi.

Kemudian dilanjutkan dengan penyampain materi menggunakan metode 
presentasi dan disertai dengan jaring-jaring kubus terbuat dari karton. Sehingga siswasiswi dapat melihat dengan jelas, dan tim berharap siswa-siswi dapat lebih mudah memahami materi tentang kubus, baik dari konsep sampai perhitungan. Kemudian setelah pemaparan materi kubus selesai, tim memberikan contoh-contoh dan penyelesaian kasusnya.

Kemudian terakhir tim memberikan pertanyaan terkait materi yang telah dijelaskan sebelumnya dan kegiatan berlangsung tertib serta menyenangkan. Tidak ada siswa-siswi yang bosan dengan kegiatan ini, karena pembelajaran dilakukan dua arah antara tim abdimas dengan siswasisiwi. Keberanian dan rasa percaya untuk menjawab pertanyaan setelah materi dijelaskan sangat baik, sehingga kedepannya proses kegiatan pembelajaran dapat terlaksana dengan baik.

\section{Kesimpulan}

Kegiatan pengabdian masyarakat yang dilakukan ini sangat perlu dan dirasakan manfaat bagi peningkatan proses belajar mengajar disekolah. Kegiatan ini juga memberikan kontibusi yang positif untuk memantapkan pemahaman materi tentang kubus, mulai dari konsep hingga perhitungan dan dapat disimpulkan sebagai berikut :
1. Siswa-siswi memahami konsep kubus bangun ruang dengan baik menggunakan modul dan jarring-jaring kubus.

2. Diperlukan pembelajaran yang kreatif dan inovatif agar siswa siswi lebih mudah memahami materi bangun ruang terutama kubus dalam proses belajar mengajar di kelas.

3. Materi pembelajaran bisa menggunakan modul dan jaring-jaring bangun ruang sehingga lebih mudah dipahami dan menyenangkan bagi siswa-siswi.

\section{Daftar Pustaka}

Depdiknas. 2002. Pengembangan Pelaksanaan Broad-Based Education, High Based Education dan Life Skill di SMU. Jakarta : Depdiknas.

Depdiknas. 2006. Materi Panduan Silabus dan Panduan Pengembangan Rencana Pelaksanaan Pembelajaran (RPP) Sekolah Menengah Pertama (SMP) Mata Pelajaran Matematika. Jakarta: Departemen Pendidikan Nasional

Hudojo, Herman. 2005. Pengembangan Kurikulum dan Pembelajaran Matematika. Malang:Universitas Negeri Malang Press. 